\title{
Implementations of Smart Cities in USA, Europe, and the Far East Countries
}

\author{
Fatima AlQaoud ${ }^{1}$, Andrew Carruthers ${ }^{2}$, Mumtaz Kamala ${ }^{3}$, and Raed Abd-Alhameed ${ }^{4}$ \\ \{fnhalqao@bradford.ac.uk ${ }^{1}$, A.Carruthers@bradford.ac.uk ${ }^{2}$, m.a.kamala@bradford.ac.uk $\left.{ }^{3}\right\}$ \\ Kuwait University, Block 4, Al-khaldiya, Kuwait ${ }^{1}$ \\ Faculty of engineering and informatics, University of Bradford, Bradford, BD7 1DP, UK ${ }^{2,3}$ \\ Information and Comms Eng. Dept., Basrah University College of Science and Technology, Basrah \\ 24001, Iraq $^{4}$
}

\begin{abstract}
This paper presents definitions of the 'Smart City' that have been discussed academically and examines different implementations of the smart city in the United States and some European countries such as the United Kingdom, Germany, and Far East countries such as Japan, South Korea, and Singapore. With the emergence of many global problems such as climate change, transportations, high populations, limited resources of food and medicine, all developed countries must amalgamate their efforts and cooperate to find an ultimate smart city, considering the most appropriate standards for constructing such a city. This paper also presents a comparison of different implementations of the smart city and various initiatives which have been undertaken by different countries to solve worldwide problems.
\end{abstract}

Keywords: Smart City, virtual environment, Online learning, online environment, smart environment, online system, ICT, technology, educational system, Society 5.0, U-City, sensor deserts, sustainability.

\section{Introduction}

Engaging with the technology era has required all government departments and private sectors to share the same database and compatible systems to use the same information to operate it in a way that enables them to process, proceed, and manage operations related to citizens or clients. Researchers have been conducting investigations into the recent technological developments and they describe the city or the country that implements the most advanced technology as the 'Smart City' to indicate the progress of the country economically, socially, and academically.

To be classified as a smart city, several projects must be accomplished; thus, it is important to shed light on the definition, concept, and principles of the 'Smart City' from the perspective of academic research[1]. The size of the city can determine certain characteristics that shape an ideal smart civilized city because it is dependent on its accessibility to other cities and accessibility to service centres; thus, governments should consider inhabitants, size, and proper functions to construct a smart city [2]. Thus, smart citizens, smart thriftiness, smart management systems, and smart environment are characteristics of smart city construction [3].

Previous studies such as that by Caragliu [4], have proposed that similar schemes and solutions have been defined using several terms but with close similarities with one another. For example, 
intelligent city, wired city, and digital city have a similar meaning; however, similarities and variations were not yet determined in these terms. On the other hand, Chen [5] insists that technology is the main constituent for the smart city and in particular ICT, which enables links to be made to different agents in the civilized arena and to provide technical services. The most significant agents are universities, research institutions, and companies with high technology [6, 7]. Dameri [1] introduced the definition of a smart city relying on three characteristics which are: terminology; components and boundaries and scope. Similarly, 'Smart Cities' are considered as ecosystems that are defined as interacted organisms in communities and their environment and described as complex shaped networks through interdependent resources [8]. Ecosystems consist of agents, organizations, material infrastructures, and symbolic resources that are independently collected into a social system [9].

Hollands (2020) [10] summarised three difficulties to established definitions of a smart city, such that the term 'smart city' appeared to be based on assumptions by an academic which became conflated with another one. The second difficulty is filtering the promotion and use of such terms for marketing reasons [11-13] as disagreeing to referring to the current infrastructural change or proof of practical and effective IT legislations. The third problem is that those terms imply a positive and uncritical viewpoint regarding urban progress.

This work highlights several Smart Cities that have been implemented by different countries, in the United States, Europe, and the Far East to draw comparisons between them.

\section{Smart City in the United States and Europe}

It is noticed that ideological representation of crisis usually related to smartness emerged before 2008 from the emphasis on sustainability and climate change to post-financial crisis combat with entrepreneurship and phantomization. Recently, the United States and Europe have adopted deviating paths towards having control over big technology companies in local and international markets [14]. However, the relationship between the expected media vision of smartness and their change must be considered since it started as a space in which expectations and calculations of societal futures are created at present [15-17].

\subsection{United States}

Generally, technological industries have relied on algorithms, artificial intelligence, and machine learning to become well-known in the market. However, recently those industries have been focusing on climate change which is the new direction to form a new vision of the smart city. For instance, in the early 2000s, energy scarcity and sustainability were the main challenges to both Cisco and IBM's initial propositions about smart cities. Cisco was asked to act towards alleviating climate change and specifically to launch the Connected Urban Development (CUD) program to increase the efficiency of traffic flow through new technologies, thereby decreasing carbon emissions. Several cities took advantage of such a project including San Francisco, Seoul, Amsterdam, Madrid, and Hamburg. To form cities to be a model of infrastructural efficiency; Cisco stated that 'Our fundamental belief is that today's flow of people, goods, energy, information, media, and services in cities can be as efficient as the traffic of digital products on the internal'[18]. Likewise, IBM's president and CEO Samuel Palmisano declared their vision of a 'Smart Planet' in 2008 in a speech to the Council on Foreign Relations., announcing that cities that share similar crisis ideological representations facing several 
difficulties and threats to their long-life existence across all their central systems that they need to outline holistically, IBM's program recommended that technology must be used by a smart city to shift its central systems and optimize the return from largely limit resources[19].

\subsection{United Kingdom}

By 2020, cities are expecting to spend US\$ 20 billion on sensor technologies [20]. Smart city agendas have appeared during the post-2008 era following an economic recession crisis and raising worldwide and regional injustice. Most cities are now more unevenly divided between rich elites and those in poverty than during the past decade, despite the level of wealth generation that has not been seen before [21]. New sensor technologies contact social procedures and they can present well-documented social and environmental inequalities [22]. 'Sensor deserts' is a term that refers to a situation that arises when attempting to produce new data and knowledge about cities, where gaps appear in understanding the exact urban population. However, networks cannot cover all areas, despite their tendency to give signals of ubiquity regarding an urban environment. Therefore, sensor deserts are a smart-specific term for inequalities, focused on areas that have a scarcity of coverage as well as a poor investment, conceptual, and legality related to smart cities[23].

'Sensor deserts' are deserts in sensor coverage where it is difficult to collect data; these become obvious in physical sensor infrastructure and the data they yield. They can be attached to lampposts or fixed on kerbsides. Their function is to indicate investment priorities and therefore, that people and places are recognised as important by smart city efforts. Changing the place of sensor infrastructure from the gaps and following biases in collected data. Significantly, sensors cannot cover all areas and are selective in terms of positioning. Consequently, Robinson [23] conceptualised and analysed sensor deserts through two case studies: Newcastle's Urban Observatory (UK) and Chicago's Array of Things (USA); despite the limitations these studies faced, the results demonstrated best practice in the design of fair sensor networks [23].

\subsection{Germany}

The primarily top-down smart city strategies adopted in Germany have led to considering raising bottom-top activism to retrieve the urban commons [24-27]. This requires keeping the capitalist sense for more democratic, community-based dominant away from governance practices, legislations, and infrastructure[28]. Constructing a smart city is not only limited to ICT and digital enhancement fixed market-economic sense [29, 30], but also have been prepared to satisfy urban sustainability, approaches, and strategies which concentrated on the "enhance efficient skills, the individual and household behaviour, and settlement of consumer culture' [31].

Smart City Cologne (SCC) emerged in 2011 aiming to protect the environment by creating a sustainable and resilient city[32]. To that purpose, the local energy provider "RheinEnergie" (RE) and the city of Cologne entered a partnership. The implementation of SCC has influenced both austerity-inclined financial policies and the federal government's Energiewende (Energy Transition) policy. German municipalities have experienced a continuous rise in debts and a decline in leverage to enforce taxes on commerce and land, because of the high competition among cities to gain more business and private capital [33]. In the 1980s, when Germany attempted to implement de-industrialisation, the city of Cologne concentrated on economic development and setting up strong occupation markets, through a partnership of public and private sectors and cost efficiency considerations in planning [34]. 
Citizens' engagement was regarded as the overriding feature of SCC (Smart City Cologne Website), and the website of SCC encouraged all people to participate and the approach was "bottom-up" in its aim, therefore, in this development, re-politicisation of smart city strategies and social innovation is seen to be independent on each other[28].

\subsection{Spain}

To design and build a successful smart city, vendors of applications and software system developers must understand all needs and requirements of a smart city. Therefore, it is important to know which software systems that international organizations are offering (open or close), those software systems to which smart city axes are related, to which communication technologies that the smart city system is compatible with, and what the software solutions have been designed for [35].

Urban planners and policymakers need to make the best decisions when choosing software systems to implement and construct smart cities. Giffinger et al.[36] presented a guide as a standard to lead platform providers to determine the domains of work as shown in Fig 1. [36]. The figure shows that smart cities fall into six different axes: Smart economy- that is related to economic competencies; Smart environment- that can be described by natural conditions such as climate, green space, in addition to the management of pollution and resource management; Smart governance- that comprises aspects of political engagement and citizen services; Smart living- this consists of different aspects of life quality, health, safety, and housing; Smart mobility- which concerns the transport systems and communication technology; and eventually, Smart people- that represents social interactions and human life.

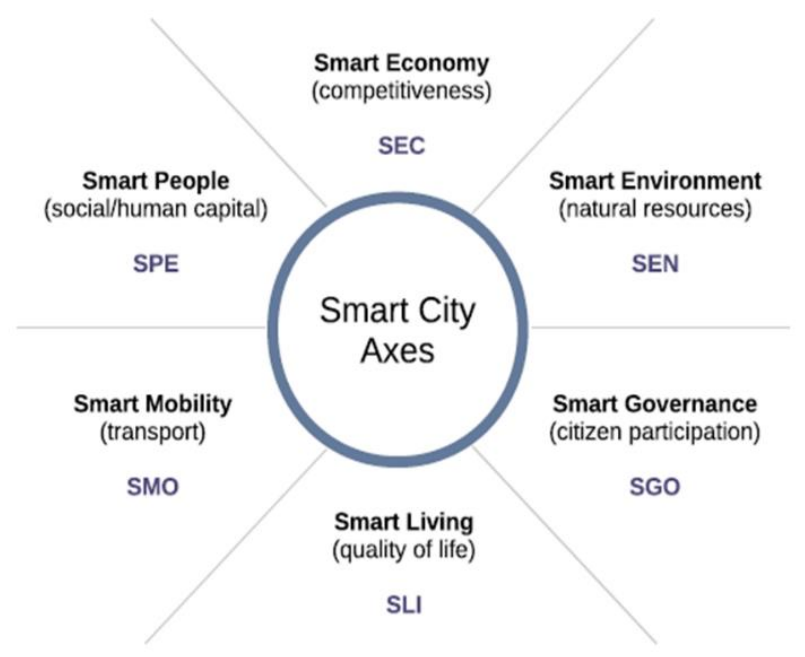

Fig 1. Six axes of a Smart City (Adopted from Giffinger (2007)[36]).

Saborido [35] states that two main obstacles impede the implementation of a powerful smart city solution. First, the utilization of ICT, which had relied on traditional systems that are not interoperable and now need to be upgraded as they are not mobile across cities, are not able to expand nor are they cost-effective. The second obstacle relates to some of the architectural design achievements which are currently in the process but have not yet combined, and this 
issue raises some concerns for stakeholders. However, the researcher offers a solution in terms of the contributions of international standards organizations, professional organizations, and international communities which will minimize the impacts of such obstacles. Saborido [35] demonstrates how such organizations can cooperate to form Smart City Standardizations as shown in Fig 2. [35] below.

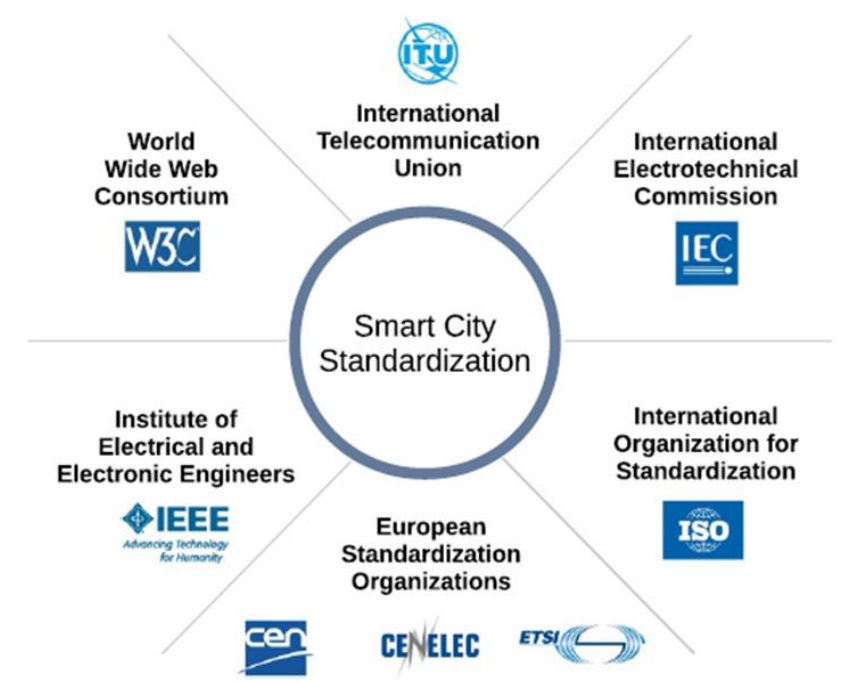

Fig 2. International standards of organizations to build up the smart city (Adopted from[35]).

The lack of interoperability among platforms causes confusion and differences of standards and prevents the timely evolution of low-level IoT Technologies which slows down services to be delivered by smart cities [37]. Several recent smart cities have relied on closed systems, in which the interior design and architecture were anonymous. This is the opposite of the open systems that are based on components that are compliant with manufacturing standards. Therefore, it is recommended that policy-makers and urban planners use software systems that present public Application Programming Interface(APIs) because this signifies that the vendors are authorized to use software functions and features compatible with the requirements of smart cities [35].

\section{Smart City in the Far East}

With the emergence of smartphones, people have practiced a new way of shopping, new ways of performing their jobs, and new ways of exporting and importing services. This development has involved a significant change that has been witnessed over the past 30 years due to digital technology, which has contributed to transforming societies from an industrial society based on fabrication into an information-based society [38]. According to the International Electrical Commission [39], it is expected that $66 \%$ of the global population will live in urban regions by 2050 . Therefore, basic needs such as energy, clean water, sufficient food must be supplied in ways that are compliant with the need for economic, social, and environmental sustainability [40]. 


\subsection{Japan}

Information Communication Technologies (ICT) enable initiatives related to smart cities to be taken. ICT is viewed as a fundamental factor to help cities to enhance transformative solutions to detect the problems of global change and build up sustainable and resilient communities. Such solutions are essential to enhance urban sustainability, integrating intelligent basic rules with sustainability measure tools [41].

Due to current situations related to the growth of cities and demand for services, the realization of 'super-smart city' was given top priority for developed countries and considered as the first pillar in the $5^{\text {th }}$ Science and Technology Basic Plan [42], and "Society 5.0" is considered one of the most popular initiatives towards this realization [43]. ICT is being used as a digital infrastructure regarding catastrophe countermeasures in Japan specifically this includes the use of social media such as 'twitter' and Geographic Information Systems (GIS) that played a key role in catastrophe countermeasures. Since the real world and virtual spaces have close relationships and have become integrated into super-smart city societies such as in Japan, this has led to the sharing of information in virtual space which helps to support activities in the real world. Therefore, if a disaster in the real world happened, the reception of disaster-related information would be readily available and broadcast in virtual space through different information communication channels simultaneously [43].

It is important to highlight an exceptional experience of Japanese technology; Deguchi [38] presented a vision of a future society called 'Society 5.0', which is guided by scientific and technological innovation in Japan such that; according to this concept as shown in Fig 3. [38]: "The first step of combining the physical space as 'the real world' with the cyberspace by supporting ICT to its fullest, suggesting an optimal form of Japanese future society, which can be described as a 'super-smart society' which will make people wealthier. The series of such innovations are being now more deepened and intensively advertised as 'Society 5.0"'. According to Deguchi [38], Society 5.0 is a model used to connect the government's vision of a future society to manufacturing and the general public. Therefore, it is important to understand the basic ideas to obtain a complete picture of 'Society 5.0', as well as cyberspace and physical space to satisfy the concept of 'Society 5.0 '.

\subsection{South Korea}

South Korea has the necessary experience required to build smart cities as national basic industries to grow the economy. Despite the challenges faced by the government such as a declining economy, and inability to achieve smart functionality to the U-City, the government has implemented policies and legislations for smart cities such as 1) promoting and implementing solutions for South Korean smart cities 2) implementation of developed technology and governmental action which had been suggested by majority public opinion 3) requirements of a wide scope approach and strategic plan which integrates software applications with developed technologies; 4) engagement of private and public sectors through investments to achieve social progress [44].

In the early 2000s, South Korea established the U-City before the smart city term appeared. The U-City "Ubiquitous City Act" was constructed to manage the transportation, environmental, and energy-related problems of cities. According to[45], the expression 'Smart City' has replaced the term 'U-City' after Apple released the iPhone in 2007. The smart city is the most popular concept that concerns building a low-cost, high-efficiency space to set up social capital since 
the U-City was created as an integrated system for effective use of information through the construction of ICT-based solutions [46].

Recent smart city policies of each ministry in South Korea concentrate on technology enhancement and the configuration of integrated systems, as well as consumer-oriented services since policies of smart city, have been developed to promote the smart city and to be extended to serve international markets [47]. Different projects have been used under different names such as U-City and e-city by several ministries in South Korea causing conflicts in objectives, directions, strategies, and weak cooperation among them; therefore, using the big data-based approach indicates the general tendency of the smart city in South Korea. Smart cities appeared as a solution to different future urban challenges such as global warming, energy problems, and high population [44].

\begin{tabular}{|c|c|c|c|c|c|}
\hline Society & Hunter-gatherer & Agrarian & Industrial & Information & Super smart \\
\hline 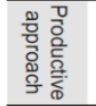 & Capture/Gather & Manufacture & Mechanization & ICT & $\begin{array}{c}\text { Merging of } \\
\text { cyberspace and } \\
\text { physical space }\end{array}$ \\
\hline Material & Stone $\cdot$ Soil & Metal & Plastic & Semiconductor & Material $5.0^{\star}$ \\
\hline Transport & Foot & Ox, horse & $\begin{array}{c}\text { Motor car, boat, } \\
\text { plane }\end{array}$ & Multimobility & $\begin{array}{c}\text { Autonomous } \\
\text { driving }\end{array}$ \\
\hline 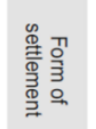 & $\begin{array}{l}\text { Nomadic, small } \\
\text { settlement }\end{array}$ & Fortified city & $\begin{array}{l}\text { Linear (industrial) } \\
\text { city }\end{array}$ & Network city & $\begin{array}{l}\text { Autonomous } \\
\text { decentralized city }\end{array}$ \\
\hline $\begin{array}{l}\text { City } \\
\text { ideals }\end{array}$ & Viability & Defensiveness & Functionality & Profitability & Humanity \\
\hline
\end{tabular}

Fig 3. Contextualizing Society 5.0. Categories created by the authors. Source: Produced by authors. $*$ Research conducted by the University of Tokyo's Material Innovation Research Centre-According to Deguchi [38]

\subsection{Singapore}

Singapore has achieved a highly context-sensitive sustainable city through focusing on farming and conceiving smart urban initiatives and schemes. Constructing a smart city in Singapore required reshaping an urban environment that had relied on shifting from a 'Smart in a box' product version to a 'Smart in the city's approach. The most common feature of the urban condition is coping with large-scale growth to transfer to megacities through continuous urbanization which handles the issues of high energy consumption, crowded vehicles, greater consumption of natural resources, and rapid population growth [48]. According to [49, 50], the most prevalent highly ranked smart cities are Singapore, Barcelona, New York, Amsterdam, and London, which share similar advanced infrastructure of towns such as Songdo (South Korea) or Masdar (Abu Dhabi-UAE). These developments are provided as models for building smart cities. Despite differences among these cities, they all share the same characteristics such as successful growing cities, handling problems of high population, and the effective management of mobility. Therefore, to shift from 'Smart in a box' to 'Smart in the City, people and citizens who live in them must be engaged to be the main component of the smart city rather than technology. This has been pointed out by Hollands [51] who stated that the smart city can 
become more economically, socially, and culturally polarized and divided by raising divisions between received knowledge and creative workers, and the non-competent and IT ignorant people [52, 53].

In the same manner, to achieve smart city goals; communication, interaction, involvement, and contributions of basic components must be considered. This should include collecting and accessing usage-based data and feedback from end-users that can be used to enhance existing services. This can be accomplished by taking advantage of smartphones, the Internet of Things (IoT), and cloud computing technology. Participation of government agencies such as profit organizations (for example, Startups, major tech firms, and legacy businesses) as well as nonprofit organizations in the ecosystem through addressing solutions and developing pilots will lead to the appropriate mechanisms to align incentives [54].

\section{Result and Discussion}

All countries around the world are facing the same ecosystem problems such as climate change, high emission of carbon from industries, trains, airplanes, and cars, as well as high population growth with limited resources of food and medicines. Consequently, most developed countries have changed their direction from manufacturing and producing with more advanced recognition to the creation of smart cities, which will achieve a sustainable environment for all people around the world to live longer and healthier.

Countries in the West such as the USA and Europe, for example, The United Kingdom, Germany, and Spain as well as countries in The Far East e.g.: Japan, South Korea, and Singapore; have taken actions towards resolving global issues as shown in Table 1. As we can see, the United States, like Germany, is working to find solutions for climate change. The USA has engaged Cisco to release the Connected Urban Development (CUD) program to increase the efficiency of traffic flow through new technologies, thereby decreasing carbon emissions. Germany implemented the Smart City Cologne (SCC) as a sustainable and resilient city to protect the climate and to minimise rising debts due to the decline in leverages to enforce taxes on commerce and land, through the partnership between the local energy provider "RheinEnergie" (RE) and SCC. Additionally, citizens have been engaged as a basic structure of SCC.

On the other hand, The United Kingdom spent efforts to build up a network as 'sensor deserts' that can cover all areas and are selective in terms of positioning to gather precise data and information. Similarly, Japan has dedicated its efforts to building the Society series and now has released 'Society 5.0' which can be used to combine the real world with virtual spaces for effective sharing of information. This helps to support activities in the real world and by effectively dealing with catastrophic events. Both the UK and Japan are seeking for accuracy of the information, while South Korea has its own experience with different systems that have been used by different ministries. Therefore, the smart city concept has appeared as a unified solution to be used among all ministries to solve different future urban challenges such as global warming, energy problems, and high population. Likewise, Singapore started 'smart in a box' and transformed to 'smart in a city' to handle the issues of high energy consumption, crowded vehicles, increased consumption of natural resources, and rapid population growth. In agreeing with Germany's policy, citizens who live in them must be engaged to be the main component of the smart city rather than technology, as well as encouraging profit and non-profit organizations to participate in building up the smart city [54]. 
Table 1. Initiatives used to implement smart cities in the USA, Europe, and the Far East.

\begin{tabular}{|c|c|c|c|}
\hline Country & Initiative & Purpose & Smart City \\
\hline USA & $\begin{array}{l}\text { Connected Urban } \\
\text { Development (CUD) program }\end{array}$ & $\begin{array}{l}\text { to increase the efficiency } \\
\text { of traffic flow through new } \\
\text { technologies, thereby } \\
\text { decreasing carbon } \\
\text { emissions }\end{array}$ & $\begin{array}{l}\text { San Francisco, } \\
\text { Seoul, } \\
\text { Amsterdam, } \\
\text { Madrid, and } \\
\text { Hamburg }\end{array}$ \\
\hline UK & Sensor deserts network & $\begin{array}{l}\text { to indicate investment } \\
\text { priorities, therefore, } \\
\text { people and places are } \\
\text { recognised by smart city } \\
\text { efforts }\end{array}$ & $\begin{array}{l}\text { Newcastle, } \\
\text { Chicago }\end{array}$ \\
\hline Germany & Smart City Cologne (SCC) & $\begin{array}{l}\text { to protect the climate to } \\
\text { be a key sustainable and } \\
\text { resilient city, and to } \\
\text { achieve a stable raise in } \\
\text { debts and a decline in } \\
\text { leverage to enforce taxes } \\
\text { on commerce and land }\end{array}$ & Cologne \\
\hline Japan & Society 5.0 & $\begin{array}{l}\text { catastrophe } \\
\text { countermeasures }\end{array}$ & Japan \\
\hline $\begin{array}{l}\text { South } \\
\text { Korea }\end{array}$ & $\begin{array}{l}\text { U-city "Ubiquitous City Act" / } \\
\text { e-city }\end{array}$ & $\begin{array}{l}\text { to manage the } \\
\text { transportation, } \\
\text { environment, and energy- } \\
\text { related problems of cities, } \\
\text { and to find a solution to } \\
\text { different future urban } \\
\text { challenges such as global } \\
\text { warming, energy } \\
\text { problems, and high } \\
\text { population }\end{array}$ & $\begin{array}{l}\text { Several } \\
\text { ministries }\end{array}$ \\
\hline Singapore & $\begin{array}{l}\text { Smart in a box / Smart in the } \\
\text { city }\end{array}$ & $\begin{array}{l}\text { to transfer to megacities } \\
\text { through continuous } \\
\text { urbanization which handle } \\
\text { the issues of high energy } \\
\text { consumption, crowded } \\
\text { vehicles, more } \\
\text { consumption of natural } \\
\text { resources, and the quick } \\
\text { growth of population. }\end{array}$ & Singapore \\
\hline
\end{tabular}

\section{Conclusion}

Developed countries are competing to construct the ultimate smart city as a sustainable environment to solve many worldwide problems such as climate change, transportation, traffic flow, and energy-related problems of cities. However, no single solution has emerged, despite different efforts that have been made to construct a smart city. Since no standardisation of the main components of a smart city, each city has released its initiative for similar purposes.

Urban planners and policy-makers need to make the best decisions when choosing software systems to implement and construct smart cities. Spain calls for contributions of international standards organizations, professional organizations, and international communities to set up 
unified standards that all developed countries can utilize when setting up smart cities. Specifically, Giffinger et al. [36] presented a guide as a standard to lead platform providers to determine the domains of work, to construct a smart city. Additionally, governmental parties, citizens, profit and non-profit organizations need to be participants in setting up a smart city.

\section{References}

[1] R. P. Dameri, "Searching for smart city definition: a comprehensive proposal," International Journal of computers \& technology, vol. 11, no. 5, pp. 2544-2551, 2013.

[2] R. Katoshevski-Cavari, T. A. Arentze, and H. J. P. Timmermans, "Sustainable city-plan based on planning algorithm, planners' heuristics and transportation aspects," Procedia-Social and Behavioral Sciences, vol. 20, pp. 131-139, 2011.

[3] A. Kirimtat, O. Krejcar, A. Kertesz, and M. F. Tasgetiren, "Future trends and current state of smart city concepts: A survey," IEEE Access, vol. 8, pp. 86448-86467, 2020.

[4] A. Caragliu, C. D. Bo, and P. Nijkamp, "Smart Cities in Europe «3rd Central European Conference in Regional Science-CERS," A13 L, vol. 90, p. O18, 2009.

[5] Y.-T. Chen, "Sketch industry promotion framework for smart living services by leveraging living lab harmonization cube," International Journal of Electronic Business Management, vol. 10, no. 2, p. 149, 2012.

[6] E. Cosgrave and T. Tryfonas, "Exploring the relationship between smart city policy and implementation," 2012, pp. 79-82.

[7] R. P. Dameri, "Defining an evaluation framework for digital cities implementation," 2012: IEEE, pp. 466-470.

[8] U. Gretzel, H. Werthner, C. Koo, and C. Lamsfus, "Conceptual foundations for understanding smart tourism ecosystems," Computers in Human Behavior, vol. 50, pp. 558-563, 2015.

[9] D. Maheshwari and M. Janssen, "Reconceptualizing measuring, benchmarking for improving interoperability in smart ecosystems: The effect of ubiquitous data and crowdsourcing," Government Information Quarterly, vol. 31, pp. S84-S92, 2014.

[10] R. G. Hollands, "Will the real smart city please stand up?: Intelligent, progressive or entrepreneurial?," in The Routledge Companion to Smart Cities: Routledge, 2020, pp. 179-199.

[11] I. Begg, Urban competitiveness: policies for dynamic cities. Policy Press, 2002.

[12] D. Harvey and F. D. Harvey, Spaces of hope. Univ of California Press, 2000.

[13] J. R. Short, C. Breitbach, S. Buckman, and J. Essex, "From world cities to gateway cities: Extending the boundaries of globalization theory," City, vol. 4, no. 3, pp. 317-340, 2000.

[14] B. Baykurt and C. Raetzsch, "What smartness does in the smart city: From visions to policy," Convergence, vol. 26, no. 4, pp. 775-789, 2020.

[15] V. Albino, U. Berardi, and R. M. Dangelico, "Smart cities: Definitions, dimensions, performance, and initiatives," Journal of urban technology, vol. 22, no. 1, pp. 3-21, 2015.

[16] A. Cocchia and R. P. Dameri, "Exploring smart city vision by university, industry and government," in Blurring the boundaries through digital innovation: Springer, 2016, pp. 259270.

[17] O. Halpern, R. Mitchell, and B. D. Geoghegan, "The smartness mandate: Notes toward a critique," Grey Room, pp. 106-129, 2017.

[18] N. Villa and S. Mitchell, "Connecting cities achieving sustainability through innovation," 2010.

[19] S. Dirks and M. Keeling, "A vision of smarter cities: How cities can lead the way into a prosperous and sustainable future," IBM Institute for business Value, vol. 8, 2009.

[20] SmartCitiesWorld. "Smart city technology market to grow by $\$ 263$ billion by 2028." (accessed June, 6 2021, 2021).

[21] UN-Habital. "World Cities Report 2016: Urbanization and Development." (accessed June 1 2021, 2021). 
[22] S. Safransky, "Geographies of algorithmic violence: redlining the smart city," International Journal of Urban and Regional Research, vol. 44, no. 2, pp. 200-218, 2020.

[23] C. Robinson and R. S. Franklin, "The sensor desert quandary: What does it mean (not) to count in the smart city?," Transactions of the Institute of British Geographers, 2020.

[24] A. Baier, T. Hansing, C. Müller, and K. Werner, Die welt reparieren: open source und selbermachen als postkapitalistische praxis. transcript Verlag, 2016.

[25] A. Follmann and V. Viehoff, "A green garden on red clay: creating a new urban common as a form of political gardening in Cologne, Germany," Local Environment, vol. 20, no. 10, pp. 1148$1174,2015$.

[26] L. Hatzelhoffer, Smart City konkret: Eine Zukunftswerkstatt in Deutschland zwischen Idee und Praxis; Evaluation der T-City Friedrichshafen. Jovis, 2012.

[27] J. Stollmann et al., Beware of smart people! Redefining the smart city paradigm towards inclusive urbanism: Proceedings of the 2015 "Beware of Smart People!" symposium. Universitätsverlag der TU Berlin, 2016.

[28] S. Leitheiser and A. Follmann, "The social innovation-(re) politicisation nexus: Unlocking the political in actually existing smart city campaigns? The case of SmartCity Cologne, Germany," Urban Studies, vol. 57, no. 4, pp. 894-915, 2020.

[29] N. Taylor Buck and A. While, "Competitive urbanism and the limits to smart city innovation: The UK Future Cities initiative," Urban studies, vol. 54, no. 2, pp. 501-519, 2017.

[30] J. M. White, "Anticipatory logics of the smart city's global imaginary," Urban Geography, vol. 37, no. 4, pp. 572-589, 2016.

[31] C. J. Martin, J. Evans, and A. Karvonen, "Smart and sustainable? Five tensions in the visions and practices of the smart-sustainable city in Europe and North America," Technological Forecasting and Social Change, vol. 133, pp. 269-278, 2018.

[32] B. Möhlendick, "Köln auf dem Weg zur Smart City," Informationen zur Raumentwicklung, vol. 1, no. 2017, pp. 24-33, 2017.

[33] B. Keller, "The continuation of early austerity measures: the special case of Germany," Transfer: European review of labour and research, vol. 20, no. 3, pp. 387-402, 2014.

[34] A. Mattissek, "Die neoliberale Stadt," ed: transcript-Verl., 2008.

[35] R. Saborido and E. Alba, "Software systems from smart city vendors," Cities, vol. 101, p. 102690, 2020.

[36] R. Giffinger, C. Fertner, H. Kramar, and E. Meijers, "City-ranking of European medium-sized cities," Cent. Reg. Sci. Vienna UT, pp. 1-12, 2007.

[37] W3C. "White Paper for the Web of Things." (accessed June 1 2021, 2021).

[38] A. Deguchi, "From Smart City to Society 5.0," Hitachi-UTokyo Laboratory (H-UTokyo Lab.), p. 43,2020 .

[39] S. City. "International Electrotechnical Commission." (accessed 28 May 2021, 2021).

[40] C. S. Lai et al., "A review of technical standards for smart cities," Clean Technologies, vol. 2, no. 3, pp. 290-310, 2020.

[41] A. Sharifi, S. Kawakubo, and A. Milovidova, "Urban sustainability assessment tools: toward integrating smart city indicators," in Urban Systems Design: Elsevier, 2020, pp. 345-372.

[42] (2016). 5th

Science and Technology Basic Plan.

[43] K. Yamamoto, "Utilization of ICT as a digital infrastructure concerning disaster countermeasures in Japan," Information, vol. 11, no. 9, p. 434, 2020.

[44] C. Choi, J. Choi, C. Kim, and D. Lee, "The smart city evolution in South Korea: Findings from big data analytics," The Journal of Asian Finance, Economics, and Business, vol. 7, no. 1, pp. 301-311, 2020.

[45] C. Choi and C.-I. Kim, "The 4th industrial revolution, smart cities, and sustainable urban regeneration: A perspective study," 환경정책, vol. 25, no. 특별호, pp. 61-91, 2017.

[46] W. J. Shin, D. N. Kim, Y. T. Cho, and S. W. Park, "Comparative Analysis Research on the Difference Between U-City and Smart City for the Establishment of International 
Competitiveness of U-City-By a Comparative Analysis of Smart Cities Index Indicators and UCity Plans Established by the Local Governments in Korea," Journal of the Urban Design Institute of Korea Urban Design, vol. 16, no. 5, pp. 5-16, 2015.

[47] (2017). Smart city policies and future directions.

[48] A. Aurigi and N. Odendaal, "From "Smart in the Box" to "Smart in the City": rethinking the socially sustainable smart city in context," Journal of Urban Technology, vol. 28, no. 1-2, pp. 55-70, 2021.

[49] Chaturvedi. "Did You Know Which Are the Top 3 Smart Cities in the World?" Geospatial World. (accessed February 5, 2019., 2019).

[50] Ierek. "“List of Top 5 Smart Cities in the World,"." Ierek: Research, Knowledge, Enrichment. (accessed February 6, 2019., 2019).

[51] R. G. Hollands, "Will the real smart city please stand up? City: Analysis of Urban Trend, Culture, Theory," Policy, Action, vol. 12, no. 3, pp. 303-320, 2008.

[52] J. Peck, "Struggling with the creative class," International journal of urban and regional research, vol. 29, no. 4, pp. 740-770, 2005.

[53] D. J. Smith, "Today's control systems evolved from early pioneers' dreams," Power Engineering, vol. 100, no. 4, pp. 17-21, 1996.

[54] S. Hasija, Z.-J. M. Shen, and C.-P. Teo, "Smart city operations: Modeling challenges and opportunities," Manufacturing \& Service Operations Management, vol. 22, no. 1, pp. 203-213, 2020. 